\title{
THE APPLICATION OF TRANSFER PRICING BETWEEN RELATED PARTIES
}

\author{
Danica Rajin ${ }^{1}$, \\ Tijana Radojević
}

\author{
${ }^{1}$ Singidunum University, \\ Faculty of Economics, Finance and \\ Administration - FEFA, \\ Belgrade, Serbia \\ ${ }^{2}$ Singidunum University, \\ Faculty of Business in Belgrade, \\ 32 Danijelova Street, Belgrade, Serbia
}

\begin{abstract}
:
The aim of this paper is to provide examples of good practice in the field of transfer pricing for the fiscal year of 2014, in accordance with the Republic of Serbia regulations and the OECD guidelines on transfer pricing. The study analyzes the $\mathrm{AB}$ Belgrade company and it shows whether the transactions that the company AB Belgrade performed with related parties in 2014 are in accordance with the "arm's length" principle in order to fulfill the requirements related to transfer pricing under the Corporate Income Tax Law in the Republic of Serbia.
\end{abstract}

Key words:

transfer pricing, related parties, corporate income tax, return on sales.

\section{INTRODUCTION}

The strategic orientation of a company is defined by creating value for capital owners, where prices emerge as an important factor that is used for the exchange of products and services between its branches i.e. transfer prices. In order to define the financial strategy of a company, it is necessary to establish the method of determining the transfer price that is mainly determined by a company's orientation towards short-term or long-term objectives in the conduct of business activities. Income tax is one of the most significant government revenues, where evasion endangers the state budget Transfer prices gain importance in both theory and practice as used in the function of moving profits between countries in order to minimize profits.

Increased globalization resulted in transfer pricing becoming one of the main areas to be used by multinational companies in the future in order to deal with their economic benefits, while tax administration will be dealth with from the tax aspects (Perić, 2006).

\section{TRANSFER PRICES}

Transfer prices are determined as the prices at which goods or services are exchanged between two entities within the same company. Transfer price can be defined as "opportunity cost for a product or service, i.e. ignored value of not using transferred products in their following best alternative usability"(Figar, 2007). 
Closely inspected, transfer-pricing represents the pricing of an organizational unit i.e. the segment of an enterprise dealing with the product, service and the semi-finished product which is internally transferred and implemented in the internal market. (Tomasevic et al., 2012). Due to this internal feature, transfer-pricing is also referred to as the „internal cost“. Current interest in transfer-pricing is mirrored in modern finances which focus on research results placing transfer-pricing as one of the areas of highest interest to international accounting (Sands and Pragasam, 1997).

According to Gajic (2007), transfer prices represent informative basis for important decision making processes of the parts and the entire enterprise, which emphasizes the need for their real identification, especially from the aspect of the scope and structure activities and overall business success.

In order to define the boundaries among which transfer prices can move, it is necessary to start from the level of utilization of the existing capacity. When branch offices sell products to the level of full capacity utilization, the opportunity cost of product units is the market price. It represents the upper limit transfer price because it is not in the branch offices' that buy the products interest to pay for products at a price that is higher than the market value. In case the branch offices are working on a level lower than full capacity utilization, the opportunity cost of the unit of production is equal to its marginal cost. The marginal cost is the lower limit for the determination of transfer prices because the branch would not be paid off to sell products at prices that are below marginal costs. (Denčić, 2011)

In the Republic of Serbia, transfer-pricing is regulated by the Transfer-Pricing Rulebook as well as articles 59, 60, 61a and 62 of the Corporate Income Tax Law and articles 5 and 6 of the Tax balance Rulebook as well as the Rulebook on tax information registration which all manage the assessment of transfer-pricing. In addition to the tax balance, the related party is required to state their business' income and expenses as well. Unless a full analysis of transfer-pricing according to the "arm's length " principle is enclosed, a set of fees amounting from EUR 1,000-2,000 and additional payments related to income tax and default interest have been established. The principle of "arm's length" implies that the taxpayer is required to enclose any data reflecting the value of those transactions which would be realized on the market if they were not associated to the related party.

\section{ANALYSIS OF THE COMPANY AB BELGRADE}

$A B$ Group is a leading company specializing in products related to the use of electricity and data, where the network technology, optimization and security in the use of electricity as well as the data protection are key priorities in business.

A business enterprise purchases products from partner manufacturers who produce them according to the specifications and technical requirements set by the company, where the products are distributed under the brand AB Group.

Companies operating within the $\mathrm{AB}$ Group distribut the goods to the specified group of customers:

1. Manufacturers of electrical panel (35\% customers)

2. Electricians and electrical engineers (35\% customers)

3. Industrial companies (20\% customers)

4. Energy companies ( $2 \%$ customers)

5. Other ( $8 \%$ customers)

\begin{tabular}{lcccc}
\hline \multicolumn{1}{c}{ Indicators } & 2011 & 2012 & 2013 & 2014 \\
\hline Return on sales & 438,648 & 580,815 & 441,293 & 465,560 \\
\hline EBITDA & 32,754 & 49,081 & 12,471 & 15,786 \\
\hline EBITDA margin & $7,5 \%$ & $8,5 \%$ & $2,8 \%$ & $3,4 \%$ \\
\hline EBIT & 29,153 & 44,572 & 7,506 & 11.154 \\
\hline EBIT margin & $6,6 \%$ & $7,7 \%$ & $1,7 \%$ & $2,4 \%$ \\
\hline
\end{tabular}

Table I. Financial indicators in the AB company (in 000) for the period 2011-2014.

Source: Serbian Business Registers Agency

\begin{tabular}{lcccc}
\hline \multicolumn{1}{c}{ Indicators } & $\mathrm{X}$ & $\mathrm{Y}$ & $\mathrm{Z}$ & $\mathrm{AB}$ \\
\hline Return on sales & $1,903,1341,363,808$ & 583,347 & 441,293 \\
\hline EBITDA & 54,626 & 85,343 & 20,221 & 12,471 \\
\hline EBITDA margin & $2,9 \%$ & $6,3 \%$ & $3,5 \%$ & $2,8 \%$ \\
\hline EBIT & 24,885 & 71,362 & 18,331 & 7,506 \\
\hline EBIT margin & $1,3 \%$ & $5,2 \%$ & $3,1 \%$ & $1,7 \%$ \\
\hline
\end{tabular}

Table II. Financial indicators for 2013 of major local competitors in Serbia

Source: Serbian Business Registers Agency

Table 1 and Table 2 present the major financial indicator (EBITDA) as one of the most important measurement of a company's operating profitability. EBITDA is essentially net income with interest, taxes, depreciation, and amortization added back to it, and can be used to 
analyze and compare profitability between companies and industries because it eliminates the effects of financing and accounting decisions. The relevance of EBITDA reflects, as a way of comparing companies within and across industries. This measure is also of interest to a company's creditors. In general, EBITDA is a useful measure only for large companies with significant assets, and for companies with a significant amount of debt financing.

Major factors that may directly or indirectly have an effect on the level of prices in the industry in which the taxpayer operates:

- Reputation - the main factor in determining prices and market strength in the industry, as well as the quality that accompanies this name.

- Competition - regions where there is a high level of competitiveness have lower prices for their services.

The economic environment represents a major business risk which can strongly influence the scope of a company's business and profitability, which has especially been difficult in Serbia due to unfavorable economic circumstances.

\begin{tabular}{cccc}
\hline $\begin{array}{c}\text { No.transac- } \\
\text { tion }\end{array}$ & Transaction & Company & Amount (RSD) \\
\hline A. The transaction costs based on the Company \\
\hline 1 & Goods supply & AB Austria & $283,713,670^{*}$ \\
\hline 2 & $\begin{array}{c}\text { Over-invoicing costs - } \\
\text { licenses }\end{array}$ & AB Austria & $1,878,968.96$ \\
\hline 3 & Controlling & AB Austria & $977,380.55$ \\
\hline 4 & Goods supply A & AB Zagreb & $21,934.56$ \\
\hline 5 & Goods supply B & AB Slovenia & $146,681.26$ \\
\hline B. The transaction revenues based on the Company \\
\hline 6 & Education & AB Bosnia & $28,215.17$ \\
\hline 7 & $\begin{array}{c}\text { Over-invoicing costs - } \\
\text { transportation }\end{array}$ & AB Bosnia & $69,277.14$ \\
\hline 8 & Education & AB Zagreb & $56,430.34$ \\
\hline 9 & Goods C & AB Zagreb & $159,812.92$ \\
\hline 10 & Selling goods D & AB Slovenia & $14,785.60$ \\
\hline 11 & Marketing & AB Austria & $403,333.68$ \\
\hline & & Total revests: $286,738,635.33$ \\
\hline
\end{tabular}

Total revenue: $731,854.85$

Note: In 2014, the Company had a transaction relating to the purchase of goods from $\mathrm{AB}$ Austria in the amount of RSD $265,299,245.96$.

Table III. Transactions overview with related parties
Functional analysis is conducted to identify the functions performed by the Company in relation to the activities which it provides for its related parties or which it receives from them. This is essential for the development of policy on transfer pricing because the functions assumed by the related parties are usually correlated with the risks taken or tangible or intangible assets created. Functions, risks and assets have an important impact on their profitability related to the operations of affiliated entities.

\section{DESCRIPTION OF TRANSACTIONS WITH RELATED PARTIES}

In 2014, AB Company did have transactions with related parties. According to article 2 sections 3 and 4 of the Transfer-Pricing Rulebook and the methods of the "arm's length" principle applied in the process of cost establishment for related party transactions ("Official Gazette of RS", no. 61/2013 and 8/2014), the following table shows data on the transactions the company had with related parties in 2014 and according to which the income and the expenses of the company have been recorded.

\begin{tabular}{|c|c|c|c|}
\hline $\begin{array}{l}\text { No of } \\
\text { transaction }\end{array}$ & Type of transaction & Related parties & Amount (RSD) \\
\hline 1 & Goods supply A & AB Zagreb & $21,934.56$ \\
\hline \multirow[t]{2}{*}{2} & Goods supply B & AB Slovenia & $146,681.26$ \\
\hline & & \multicolumn{2}{|c|}{ Total costs $168,615.82$} \\
\hline 3 & $\begin{array}{l}\text { Providing educational } \\
\text { services }\end{array}$ & AB Bosnia & $28,215.17$ \\
\hline 4 & $\begin{array}{l}\text { Over-invoicing costs - } \\
\text { transportation }\end{array}$ & AB Bosnia & $69,277.14$ \\
\hline 5 & $\begin{array}{l}\text { Providing educational } \\
\text { services }\end{array}$ & AB Zagreb & $56,430.34$ \\
\hline 6 & Goods C & AB Zagreb & $159,812.92$ \\
\hline 7 & Selling goods D & AB Slovenia & $14,785.60$ \\
\hline 8 & Marketing & AB Austria & $403,333.68$ \\
\hline & & Total revenı & e $731,854.85$ \\
\hline
\end{tabular}

Table IV. Transactions overview with related parties in 2014 
According to the Corporate Income Tax Law ("Official Gazette of RS“, no. 25/2001, 80/2002,80/2002, $43 / 2003,18 / 2010,101 / 2011,119 / 2012,47 / 2013$ and 108/2013) and the Transfer-Pricing Rulebook and the methods of the "arm's length" principle applied in the process of cost establishment for related party transactions ("Official Gazette of RS “, no. 61/2013 and 8/2014), the company has disclosed essential information on each individual related parties transaction realized in 2014.

The search of the database, conducted purposefully for this research, identified a vast number of companies that were potentially comparable and among which taxpayers who did not meet the minimum required criteria of comparability were removed. The operating loss was selected as a qualitative criterion for two or more years, which eliminated 36 companies. We performed a manual selection, by examining the description of the business in order to establish an independent comparable company. Based on the results of the manual exclusion, seven companies were selected for comparative search.

\section{INDICATOR ANALYSIS}

In order to achieve the reliability of analysis, we used an interactive range of financial indicators to determine the out of reach margin transaction which is the subject of the research.

Profit level indicator (PLI) is a financial indicator that is used to analyze the profitability of comparable companies. PLI which is used for research purposes of the comparative study of transaction purchases of goods from related entities and the sales to unrelated parties represents the sales revenue (Return on sales - ROS), which is defined as operating profit divided by operating revenues generated in the test transaction.

\begin{tabular}{cccccc}
\hline No & Company & $\begin{array}{c}\text { Return on } \\
\text { sales (ROS) } \\
2011\end{array}$ & $\begin{array}{c}\text { Return on } \\
\text { sales (ROS) } \\
2012\end{array}$ & $\begin{array}{c}\text { Return on } \\
\text { sales (ROS) } \\
2013\end{array}$ & $\begin{array}{c}\text { Return on } \\
\text { sales (ROS) } \\
2011-2013\end{array}$ \\
\hline 1 & $\mathrm{~N} 1$ & $6,73 \%$ & $2,87 \%$ & $7,89 \%$ & $5,35 \%$ \\
\hline 2 & $\mathrm{~N} 2$ & $2,25 \%$ & $1,76 \%$ & $1,48 \%$ & $1,82 \%$ \\
\hline 3 & $\mathrm{~N} 3$ & $4,79 \%$ & $3,24 \%$ & $2,14 \%$ & $3,46 \%$ \\
\hline 4 & $\mathrm{~N} 4$ & $4,48 \%$ & $4,00 \%$ & $1,21 \%$ & $3,16 \%$ \\
\hline 5 & $\mathrm{~N} 5$ & $17,41 \%$ & $15,28 \%$ & $13,41 \%$ & $15,21 \%$ \\
\hline 6 & $\mathrm{~N} 6$ & $6,67 \%$ & $6,28 \%$ & $5,08 \%$ & $6,04 \%$ \\
\hline 7 & $\mathrm{~N} 7$ & $0,19 \%$ & $0,22 \%$ & $0,27 \%$ & $0,23 \%$ \\
\hline
\end{tabular}

Table V. The financial result for the seven selected similar independent companies
The summary table shows the financial results for the years 2011-2013 and the average ROS for the period of three years for a final sample of seven selected similar independent companies for tested transaction. Final sample of similar independent companies shows the average overall range. The final sample of comparable companies provides the full range of the average ROS of $0.23 \%$ to $15.21 \%$ and interquartile range from $1.82 \%$ to $6.04 \%$, with a median of $3.46 \%$. Interquartile range of realized net margins for comparable third parties is between 1.82\% and $6.04 \%$, which indicates a range of comparable margins. Return on sale for AB Group at 2.40\% was realized in the transaction of goods procurement from related parties and the sales to unrelated parties in 2014, as part of interquartile range based on margins of comparable companies, ranging from $1.82 \%$ to $6.04 \%$.

\section{CONCLUSIONS}

Transfer prices are used with the aim to shift profits to the countries called "tax havens" in order to minimize tax profits and increase profit after tax at group level, allowing multinational companies to strengthen their competitive advantage compared to the local ones. Hereby, they have direct impact on government revenues causing the state to introduce legislative solutions for the control of the sales transactions between subsidiaries. Additionally, the state introduced a rigorous independent audit of financial statements and prescribed the requirements for more detailed disclosures on transfer pricing in the notes to the financial statements.

Based on this research, we can conclude that transfer prices implemented in the intercompany transaction of goods procurement by the AB Group in 2014 are in accordance with the principle of "arm's length". Therefore, operating in accordance with "arm's length" principle which are required by Serbian law, managers in the given company do not have implications for the current business operations because there is no need of correction taxable profit in purposes of calculating the tax on corporate profit. The guidelines of this paper is to indicate the significance of treatment of transfer pricing in Serbia with the aim of potential accession to the European Union which demands harmonization of the Serbian law with the EU law.

\section{REFERENCES}

Denčić Mihajlov, K., \& Trajčevski, M. (2011). Transfer pricing in the theory and practice in multinational companies. Economic themes, 3, 397-414 
Figar, N. (2007) The costs of the company. Niš: Faculty of Economics

Gajić, Lj. (2007). Transfer pricing in the function of internal reporting. The challenges of business and financial reporting in the function of management companies and banks (XXXVIII Symposium on Zlatibor). Belgrade: Association of Accountants and Auditors of Serbia.

Perić, Đ. (2006). Transfer pricing - international tax problem. Economic Horizons, 8, 165-171.

Sands, S., \& Pragasam, J. (1997) The perceived importance of international accounting topics in the Asia-Pacific Rim: A comparative study. International Journal of Accounting, 32(2): 187-202.
Tomašević, S., Dragosavac, M., \& Kaćanski, S. (2012). Application method of determining transfer prices in the Republic of Serbia. International Conference on social and technological development - STED. Banja Luka University for Business Engineering and Management.

Transfer-Pricing Rulebook, Official Gazette of RS no. $61 / 2013$ and $8 / 2014$ 